\author{
Stawomir Judek \\ Jacek Skibicki \\ Politechnika Gdańska \\ Wydziat Elektrotechniki i Automatyki
}

\title{
Obróbka graficzna obrazu w nowoczesnych systemach diagnostyki sieci trakcyjnej jezdnej
}

\begin{abstract}
$W$ artykule autorzy przedstawiaja założenia nowej metody bezkontaktowego pomiaru położenia przewodów jezdnych sieci trakcyjnej, a także pokazujajakie znaczenie $w$ tej metodzie ma komputerowa analiza obrazu pozyskiwanego $z$ kamery. Problemem technik wizyjnych jest zmienność parametrów obrazu wejściowego (jasność, kontrast, zakres widma, krzywa gamma i in.), które sq zależne od zmieniajacych się warunków oświetlenia zewnętrznego zwiqzanych $z$ aktualna pogoda i porq dnia. Tymczasem parametry obrazu poddawanego analizie powinny być zawsze takie same lub bardzo zbliżone. Autorzy omawiaja opracowanq aplikację komputerowa, której zadaniem jest doprowadzenie parametrów pozyskanego obrazu do wymaganych wartości wyjściowych, niezależnie od ich poziomów w obrazie wejściowym.
\end{abstract}

\section{Wstęp}

Obecnie coraz częściej stosowane są nowoczesne metody pomiaru wielkości fizycznych oparte na systemach bezkontaktowych. Brak kontaktu fizycznego urządzenia pomiarowego $\mathrm{z}$ obiektem umożliwia niekiedy pomiar wielkości dotychczas niemierzalnych. Ponadto całkowita separacja pozwala na eliminację wpływu urządzenia pomiarowego na obiekt, który to wpływ zawsze występuje przy użyciu tradycyjnego sprzętu metrologicznego. Tendencja stosowania zdalnych technik pomiarowych nie omija również diagnostyki urządzeń trakcyjnych. Coraz częściej sięga się do metod wizyjnych, wykorzystując takie urządzenia jak dalmierze laserowe, kamery rejestrujące obraz $w$ różnych obszarach widma, skanery trójwymiarowe i inne. W artykule autorzy przedstawiaja problemy związane $\mathrm{z}$ zastosowaniem bezkontaktowych metod pomiarowych na przykładzie systemu diagnostyki sieci trakcyjnej jezdnej.

\section{Specyfika pomiarów bezkontaktowych}

$\mathrm{W}$ pomiarach bezkontaktowych medium transmisyjnym umożliwiającym rejestrację wybranych parametrów przez czujnik jest promieniowanie elektromagnetyczne o różnej długości fali. W pomiarach wizyjnych wykorzystuje się najczęściej promieniowanie $\mathrm{z}$ widzialnego zakresu widma $\mathrm{i}$ podczerwieni bliskiej (kamery obrazowe, dalmierze laserowe) oraz podczerwieni dalekiej (termowizja). Wyróżniamy dwie podstawowe metody pomiarów wizyjnych:

- bierna - czujnik pomiarowy rejestruje promieniowanie emitowane bezpośrednio przez obiekt badany lub odbijane od niego, przy czym źródło promieniowania nie jest związane $\mathrm{z}$ urządzeniem (np. światło słoneczne);
- aktywna - urządzenie pomiarowe zawiera źródło promieniowania nakierowane w odpowiedni sposób na obiekt badany, a jego odbity strumień trafia do sensora (np. diody laserowe czy oświetlacze).

Cechą wspólną wizyjnych technik pomiarowych jest mniejsza lub większa podatność na zaburzenia związane z obecnością promieniowania zewnętrznego. W sytuacji gdy urządzenie pomiarowe pracuje w pomieszczeniu zamkniętym problem zaburzeń nie jest zbytnio dokuczliwy. Poziom ich jest bowiem stały, i w prosty sposób można wyeliminować wpływ promieniowania zewnętrznego na pomiar. Odmienna sytuacja występuje gdy badania wykonywane są w warunkach terenowych, gdzie występuje znaczna zmienność poziomu promieniowania (oświetlenia) związana z cyklem dobowym, rocznym oraz aktualnymi warunkami pogodowymi. Oczywiście poszczególne urządzenia pomiarowe wykazują różna podatność na zaburzenia zewnętrzne. Stosunkowo najmniej wrażliwe są wszelkie układy wykorzystujące promieniowanie laserowe (np. dalmierze, skanery itp.). Z kolei tam, gdzie sygnałem pomiarowym jest obraz $\mathrm{z}$ kamery wizyjnej wpływ zmian poziomu promieniowania zewnętrznego na wynik jest największy.

\section{Interpretacja obrazów wizyjnych do celów pomia- rowych}

W sytuacji, gdy sygnałem pomiarowym jest obraz z kamery, dalsze postępowanie uzależnione jest od celu, jakiemu ma służyć dany pomiar. Stosunkowo najprostsza sytuacja występuje wówczas, gdy celem jest detekcja obecności. Systemy takie służą np. wykrywaniu obiektów na przejazdach kolejowych. Pomiar odbywa się wówczas najczęściej na zasadzie porównania $\mathrm{z}$ wzorcem. W pamięci urządzenia znaj- 
duje się obraz wzorcowy, i na podstawie analizy porównawczej wykrywane są różnice pomiędzy nim, a obrazem otrzymanym $\mathrm{z}$ pomiaru. Odporność systemu na zmienne warunki oświetleniowe $i$ pogodowe uzyskuje się stosując bazę danych obrazów wzorcowych pozyskanych w różnych warunkach, a następnie, w zależności od bieżącej sytuacji, dobiera się wzorzec najbardziej w danej chwili odpowiedni.

Znacznie bardziej złożona sytuacja ma miejsce, kiedy zastosowanie metody porównawczej nie jest możliwe. Dzieje się tak wówczas, gdy na podstawie analizy obrazu należy uzyskać konkretną wielkość pomiarowa, np. pomiar położenia, rozmiaru itp. Wówczas przed właściwą analizą obrazu konieczna jest obróbka jego parametrów (jasność, kontrast, zakres widma, krzywa gamma), tak by rezultat był zawsze jednakowy, niezależny od panujących warunków zewnętrznych. Pewne różnice występują również $\mathrm{w}$ zależności od tego, czy stosowana jest bierna czy czynna metoda pomiaru. W pierwszym przypadku jedynym źródłem promieniowania jest sam obiekt oraz naturalne i sztuczne źródła światła. Zakres zmian parametrów obrazu źródłowego jest wówczas bardzo znaczny i często uzyskanie jednakowych wyników dla skrajnych warunków pomiarowych jest praktycznie niemożliwe. Znacznie korzystniejsza sytuacja ma miejsce, gdy wykorzystuje się czynną metodę pomiaru. Możliwe jest np. zastosowanie źródła promieniowania o jednej długości fali i takiej częstotliwości, z jaką promieniowanie naturalne występuje w mniejszym natężeniu, oraz filtrów monochromatycznych przepuszczających tylko tę częstotliwość widma. W takiej sytuacji wpływ zaburzeń zewnętrznych zostanie ograniczony, ale nigdy nie będzie możliwe jego wyeliminowanie. Można również wykorzystać dobową zmienność natężenia promieniowania świetlnego i wykonywać pomiary tylko w warunkach nocnych, gdy jego poziom jest mniejszy. Widać jednak, że mimo możliwości i konieczności stosowania środków wstępnie ograniczających wpływ zaburzeń zewnętrznych na obraz pomiarowy, praktycznie zawsze musi być on poddany obróbce wstępnej i doprowadzony do parametrów potrzebnych z punktu widzenia właściwej analizy obrazu.

Techniki wizyjne $w$ nowoczesnych metodach diagnostyki sieci trakcyjnej jezdnej

Systemy diagnostyki sieci trakcyjnej jezdnej coraz częściej korzystają z wizyjnych technik pomiarowych. Dotychczas stosowane przez zarządy kolejowe pojazdy diagnostyczne są często wyposażone w skanery laserowe służące do zdalnego pomiaru zużycia przewodów jezdnych. Położenie przewodów jezdnych względem osi toru jak dotąd mierzone jest za pomocą metod stykowych opartych o odbieraki pomiarowe specjalnej konstrukcji [1]. Proponowana przez autorów metoda pomiaru położenia przewodu jezdnego, której koncepcja została pokazana na rys. 1, a szczegółowe omówienie znajduje się w [2], wykorzystuje kamerę obrazową. Rezultatem pomiaru jest zatem obraz fotograficzny. Ponieważ pomiary wykonywane będą w warunkach terenowych, parametry obrazu z kamery będą zmienne w szerokich granicach. Wywołane jest to zarówno porą dnia, jak i warunkami atmosferycznymi. Zmiany te moga również następować $\mathrm{w}$ sposób skokowy, np. w sytuacji przejazdu przez tunel lub pod wiaduktem. Zakres widma wykorzystywanego przez źródło światła, ani sposób emisji wiązki nie został jeszcze określony. Jednak niezależnie od tego, jaka metoda zostanie wybrana zawsze konieczna będzie wstępna obróbka obrazu pomiarowego.

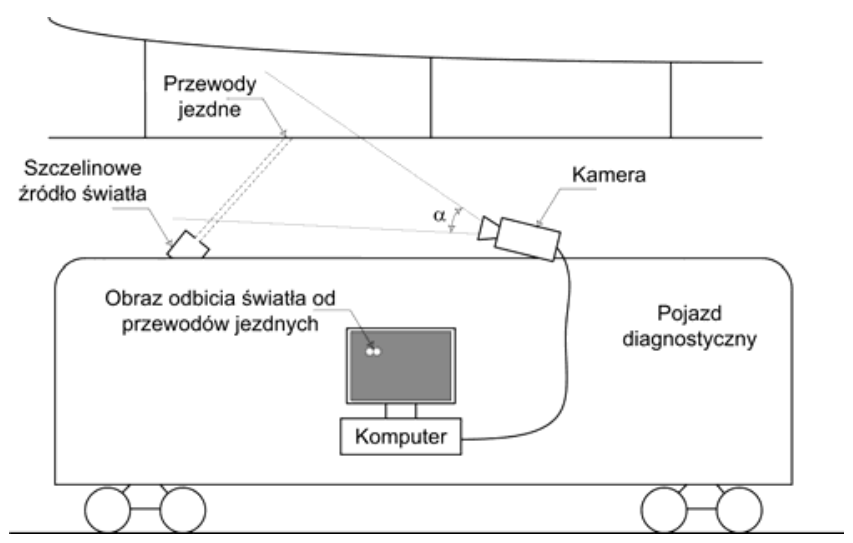

Rys. 1. Koncepcja bezkontaktowego pomiaru położenia przewodu jezdnego sieci trakcyjnej

\section{Algorytm do wstępnej obróbki obrazu}

Obraz pomiarowy przeznaczony do analizy właściwej (wyznaczenia położenia przewodu) powinien, niezależnie od parametrów wejściowych, zawierać jedynie jasną plamkę lub plamki, odpowiadające położeniu przewodu jezdnego, widziane na ciemnym (czarnym) tle. Wszystkie pozostałe informacje zawarte $\mathrm{w}$ obrazie pozyskanym $\mathrm{z}$ kamery muszą być, jako zbędne, usunięte $\mathrm{w}$ trakcie obróbki wstępnej. Główną trudnością w opracowaniu algorytmu obróbki wstępnej jest zmienny zakres operacji, jakim musi być poddany obraz, w zależności od aktualnych parametrów wejściowych. W przypadku pomiarów nocnych lub $w$ tunelach wymagana ingerencja $\mathrm{w}$ obraz jest minimalna. Diametralnie inna sytuacja ma miejsce, gdy pomiary prowadzone są w pełnym świetle słonecznym. Rezultat pracy algorytmu powinien być zawsze jednakowy, pomimo tego, że parametry obrazu wejściowego mogą się gwałtownie zmieniać nawet $\mathrm{w}$ czasie jednej sesji pomiarowej. Przy opracowywaniu algorytmu przyjęto następujące założenia:

- rezultatem działania powinien być obraz składający się z białego punktu lub punktów (będących obrazem przewodów jezdnych) na czarnym tle; 


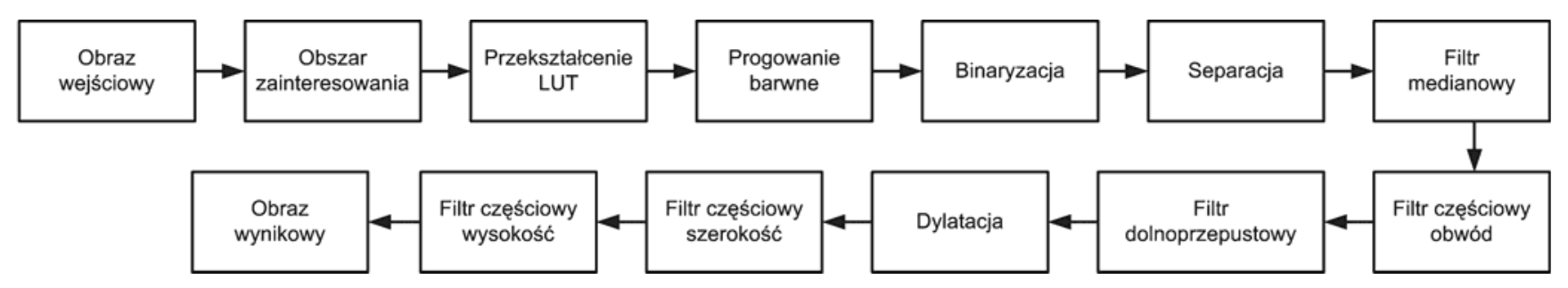

Rys. 2. Schemat blokowy algorytmu wstępnej obróbki obrazu

- $\quad$ ilość kroków powinna być jak najmniejsza;

- w sytuacji, gdy obraz o pożądanych parametrach zostanie uzyskany po mniejszej liczbie kroków, kolejne operacje nie powinny negatywnie wpływać na wygląd obrazu.

Algorytm opracowany na potrzeby badań laboratoryjnych jest dostosowany do parametrów obrazu uzyskiwanego w trakcie pomiarów. Schemat blokowy algorytmu pokazano na rys. 2. Poszczególne etapy obróbki omówiono szczegółowo poniżej $[3,4]$.

\section{Etapy obróbki obrazu}

I - Obraz wejściowy. Jest nim barwne zdjęcie fotograficzne (klatka filmu) uzyskane z kamery Samsung SHC-737 o rozdzielczości 430 kPix. Kamera pracuje $\mathrm{w}$ manualnym trybie ekspozycji, a parametry rejestracji są niezmienne bez względu na jasność obrazu. Parametry te dobrano stosownie do jasności plamki świetlnej odbijającej się od przewodu jezdnego.

II - Wyznaczanie obszaru zainteresowania $R O I$ (ang. Region of Interest). W celu przyspieszenia działania algorytmu obróbki obrazu przeprowadzana jest procedura nałożenia odpowiedniej maski zawierającej $\mathrm{w}$ sobie region zainteresowania, tj. fragment kadru, w którym w normalnych warunkach znajduje się poszukiwana plamka świetlna. Wszystkim pikselom znajdującym się poza obszarem zainteresowania zostaną przypisane wartości 0 (kolor czarny).

III - Przeksztalcanie punktowe LUT. Jednym z podstawowych przekształceń obrazu jest przekształcenie punktowe. Polega ono na zmianie poziomu szarości odrębnego piksela poprzez podanie innej wartości (różnej od pierwotnej). Podstawowymi trzema parametrami, jakie można korygować są: jasność w zakresie $<0-255>$, współczynnik gamma $<10-0,1>\mathrm{i}$ kontrast $<1-89>$. W celu przypisania pikselom wejściowym wybranego obrazu innych wartości korzysta się z tablicy LUT (ang. Look-up Table), gdzie do numeru piksela przypisuje się nową wartość. Przekształcenia punktowe wykonuje się na obrazach monochromatycznych. W przypadku kolorowych obrazów zmianie ulegają wartości poszczególnych pikseli, dla każdego kanału kolorystycznego osobno. Tablica LUT często prezentowana jest za pomocą wykresu, gdzie na osi $\mathrm{X}$ znajduja się stare, a na osi $\mathrm{Y}$ nowe wartości poziomu szarości. Na rys. 3 zaprezentowano tablicę LUT oraz odpowiadający jej wykres w przypadku zmiany jasności obrazu.

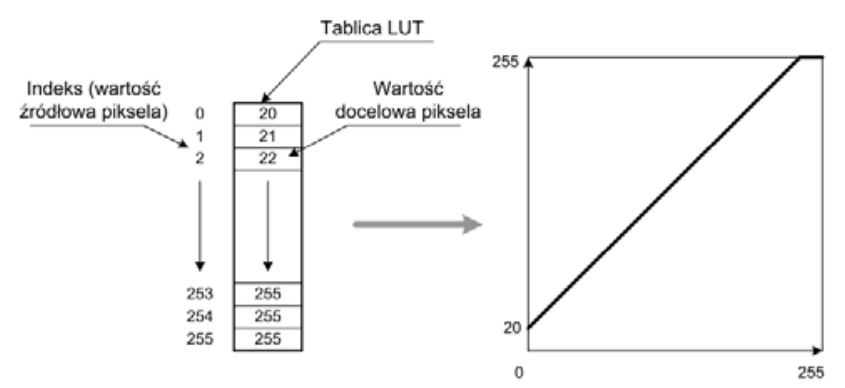

Rys. 3. Zmiana jasności z wykorzystaniem tablicy LUT

Zmiana jasności powoduje przesunięcie wykresu LUT powyżej (zwiększanie) lub poniżej (zmniejszanie) wartości pierwotnych. Przy zwiększaniu jasności oś Y przesuwana jest w kierunku wartości wyższych, oznaczających jaśniejsze obrazy. Przy zmniejszaniu natomiast tablica LUT przesuwana jest $\mathrm{w}$ stronę ciemniejszej palety odcieni.

Sterując kontrastem obrazu zmienia się stosunek luminancji maksymalnej do minimalnej, czyli ilości światła emitowanej przez daną powierzchnię. Jest to zauważalne $\mathrm{w}$ postaci różnicy pomiędzy jasnością najciemniejszego i najjaśniejszego punktu (piksela) w obrazie. Zmniejszanie kontrastu powoduje spłaszczenie charakterystyki wykresu LUT. W skrajnej pozycji (wartość kontrastu równa 1), otrzymuje się idealnie poziomą charakterystykę, co oznacza, że wszystkie nowe wartości pikseli będą takie same. Obraz wyjściowy byłby wówczas jednolitym, szarym polem (każda ze składowej RGB przyjmuje wartość 128). Drugi skrajny przypadek (kontrast równy 89) powoduje, że prawie połowa starych pikseli powiązanych $\mathrm{z}$ ciemniejszymi barwami przyjmuje wartości 0 , a z jaśniejszymi 255.

Ostatnim parametrem, jaki można regulować jest współczynnik gamma. Za pomocą funkcji nieliniowej wyszczególnia się jedne wartości pikseli względem innych, np. kontrast jasnych partii obrazu względem ciemnych [5].

W zaproponowanym algorytmie przetwarzania obrazu zastosowano przekształcenie LUT powodujące odcięcie z obrazu składowych odpowiadających kolorom zielonemu i niebieskiemu przy jednoczesnym uwypukleniu składowej czerwonej.

IV - Progowanie barwne - jedna z najprostszych metod segmentacji. Jest ona zdefiniowana jako: 


$$
I_{n}=\left\{\begin{array}{cc}
0 & I_{s}<I_{\min } \\
I_{s} & I_{\min } \leq I_{s} \leq I_{\max }, \\
255 & I_{s}>I_{\max }
\end{array}\right.
$$

gdzie: $I_{n}$ - nowa wartość intensywności, $I_{s}$ - stara wartość intensywności, $I_{\min }$ - minimalny, $I_{\max }$ - maksymalny dopuszczalny próg intensywności.

Z obrazu o trzech kolorach podstawowych RGB pobierana jest tylko jedna warstwa koloru, a mianowicie czerwona, gdyż taka jest barwa światła oświetlającego przewód jezdny. Informacje zawarte w pozostałych dwóch warstwach są usuwane. Jest to konieczne, gdyż operacja przeprowadzona w III etapie obróbki nie wyeliminowała zielonej i niebieskiej składowej widma, a stały się one jedynie niewidoczne.

V - Binaryzacja. Operacja ta ma na celu zamianę obrazu jednobarwnego na czarno-biały o charakterze graficznym (obraz dwubitowy). Wykorzystano metodę progowania poprzez entropię (metoda Kapura). Polega ona na wydzieleniu dwóch niezależnych klas rozkładów prawdopodobieństwa - obiektów $p_{o b} \mathrm{i}$ tła $p_{\mathrm{t}}$. Optymalną wartością progu $t$ jest wartość maksymalizująca całkowitą entropię [6]:

$$
H_{T}=H_{o b}+H_{t} .
$$

Rozkłady prawdopodobieństwa dla obiektu i tła prezentują się następująco:

$$
\begin{array}{cc}
\frac{p_{0}}{p_{o b}}, \frac{p_{1}}{p_{o b}}, \ldots, \frac{p_{t}}{p_{o b}} & \frac{p_{t+1}}{p_{b}}, \frac{p_{t+2}}{p_{b}}, \ldots, \frac{p_{K-1}}{p_{b}}, \\
p_{o b}=\sum_{i=0}^{t} p_{i} & p_{b}=\sum_{i=t+1}^{K-1} p_{i}
\end{array}
$$

gdzie: $p_{o b}$ - prawdopodobieństwo klasy obiektu, $p_{b}$ prawdopodobieństwo klasy tła, $p_{i}$ - prawdopodobieństwo dla danego stopnia szarości.

Entropie obu rozkładów prawdopodobieństwa wyrażają się wzorami:

$$
\begin{aligned}
& H_{o b}=-\sum_{i=0}^{t} \frac{p_{i}}{p_{o b}} \log _{2}\left(\frac{p_{i}}{p_{o b}}\right), \\
& H_{b}=-\sum_{i=t+1}^{K-1} \frac{p_{i}}{p_{b}} \log _{2}\left(\frac{p_{i}}{p_{b}}\right) .
\end{aligned}
$$

Po zakończeniu tego procesu obraz powinien składać się z białych elementów na czarnym tle.

VI - Przeksztatcenie morfologiczne - separacja obiektów. Przekształcenia morfologiczne [7] służą do usuwania wszelkiego rodzaju zakłóceń występujących w obrazie, poprzez wykorzystanie do tego celu odpowiednich wzorców. Najczęściej stosuje się je w odniesieniu do obrazów binarnych. Zakłócenie przyjmuje wtedy wartość 0 lub 1 . Istotą przekształceń morfologicznych jest zdefiniowanie punktu określającego położenie środkowego piksela (poddawanego analizie) oraz zespołu punktów go otaczających. Są to tzw. elementy strukturalne (rys. 4). a)

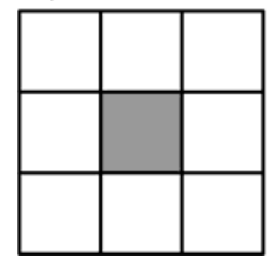

b)

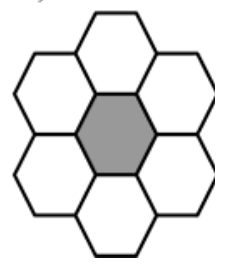

Rys. 4. Element strukturalny: a) o siatce kwadratowej; b) o siatce heksagonalnej

Schemat działania tych przekształceń polega na przemieszczaniu punktu centralnego po każdym z pikseli przetwarzanego obrazu i sprawdzaniu, czy jego otoczenie jest takie samo jak we wzorcu. Jeżeli tak jest, to stosuje się odpowiednie przekształcenie morfologiczne dla danej operacji. Do ważniejszych z nich zalicza się: dylatację, erozję, zamknięcie, otwarcie, detekcję szczytów, detekcję dolin, ścinanie, obcinanie gałęzi, szkieletyzację itp.

Erozja binarnego obrazu A przez element struktury $\mathbf{B}$ jest określona przez:

$$
\mathbf{A} \ominus \mathbf{B}=\left\{z \in \mathbf{E} \mid \mathbf{B}_{\mathbf{z}} \subseteq \mathbf{A}\right\},
$$

gdzie: $\mathbf{B}_{\mathbf{z}}-$ translacja $\mathbf{B}$ przez wektor $\mathbf{z}$ np. $\mathbf{B}_{\mathbf{z}}=\{b+\mathbf{z} \mid \in \mathbf{B}\} \mathbf{z} \in \mathbf{E}, \mathbf{E}-$ przestrzeń Euklidesowa lub macierz liczb całkowitych.

W praktyce erozja polega na przesuwaniu elementu strukturalnego w postaci ustalonej siatki po wewnętrznej stronie danej figury i pozostawianiu elementów stanowiących obszar zamknięty, ograniczony drogą narysowaną przez przemieszczający się punkt centralny elementu strukturalnego (rys. 5.). a)

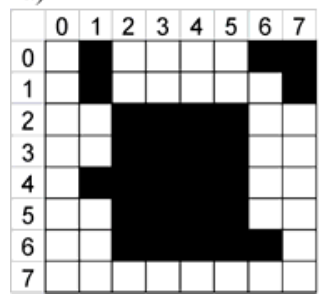

b)

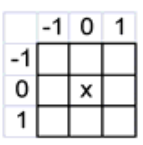

c)

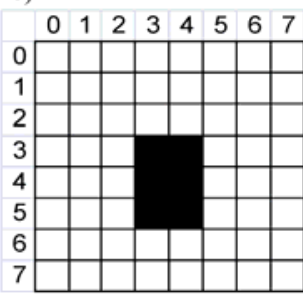

Rys. 5. Wynik działania erozji: a) obraz binarny; b) wykorzystany element strukturalny; c) obraz wynikowy

Element strukturalny przesuwa się wewnątrz największej figury obrazu binarnego (w innych wzorzec się nie mieści, gdyż składa się z 9 pól), tak że jego zewnętrzna krawędź pokrywa się z krawędzią ograniczająca figurę. Punkt centralny $\mathrm{X}$ wytycza obszar nowego obiektu, co można zaobserwować na rys. 5c. Operacja ta została wykonana zgodnie $\mathrm{z}$ definicja, która mówi, że nowe figury tworzą jedynie pola zakreślone przez środkowy piksel (reszta składowych zostaje wymazana). Można zauważyć, że erozja powoduje likwidację drobnych zanieczyszczeń występujących w obrazie, np. pola: 0-6, 0-7, 1-7. Dodatkowo ma ona wpływ na zmniejszanie rozmiarów figur poprzez ich zwężanie, w obu prostopadłych do siebie 
kierunkach. Wygładzone zostają również krawędzie obiektów. W przypadku połączenia figur drobnymi pikselami (przewężenia) można je od siebie odseparować.

Dylatacja jest pojęciem o przeciwnym działaniu do erozji i jest ściśle związana z operacją dodawania Minkowskiego. Zdefiniować ją można jako:

$$
\mathbf{A} \oplus \mathbf{B}=\bigcup_{b \in \mathbf{B}} \mathbf{A}_{\mathbf{b}} .
$$

Algorytmicznie zapisać można to jako przemieszczanie elementu strukturalnego jego zewnętrzną krawędzią po zewnętrznej krawędzi figury. Powoduje to rozrost obiektu. Obszar nowo powstałej figury tworza wszystkie piksele ograniczone krzywą wytyczona przez środek elementu strukturalnego. Przykład działania został pokazany na rys. 6 .
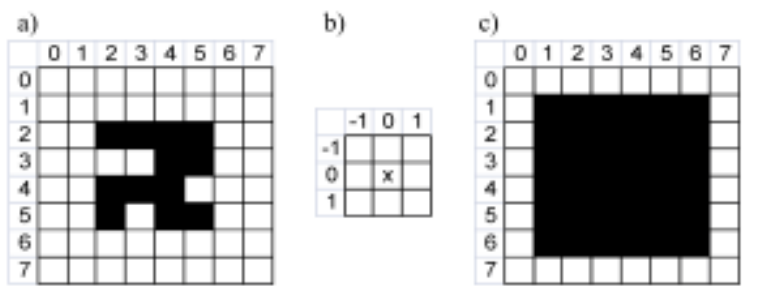

Rys. 6. Wynik działania dylatacji: a) obraz binarny; b) element strukturalny; c) obraz po operacji dylatacji

Dylatację można uzyskać tworząc negatyw obrazu powstałego w wyniku operacji erozji przeprowadzonej na negatywie tego samego zdjęcia. Stosuje się ją w celu wypełnienia małych otworów (ubytków) oraz w celu powiększenia wymiarów figury. Przedstawiony sposób działania obu metod został omówiony na przykładzie obrazów binarnych. W przypadku zastosowania ich do zdjęć kolorowych (wieloodcieniowe obrazy) uzyska się rozmycie szczegółów.

Jednym $\mathrm{z}$ podstawowych problemów stojących przed komputerową analizą obrazu jest wydzielenie poszczególnych, regularnych obszarów obrazu. Zadanie to jest szczególnie trudne, gdy poszczególne obiekty stykają się lub nawet częściowo zachodzą na siebie. Jako pierwszy krok wykonać można wtedy erozję, która rozdzieli sklejone obszary. Powstałe jednak w ten sposób obszary mają dużo mniejszą powierzchnię niż wynikowe. Aby powrócić do wyjściowej powierzchni nie można zastosować normalnej dylatacji, gdyż powiększane obszary połączą się ponownie. Aby temu zapobiec, trzeba zastosować specjalne przekształcenie, które powiększy powierzchnię obszarów zachowując pewien odstęp pomiędzy nimi. Przekształcenie to nazywane jest dylatacją bez stykania obszarów i może być realizowane jako pogrubianie $\mathrm{z}$ następującym elementem strukturalnym, którego macierz ma postać:

\begin{tabular}{|c|c|c|c|}
\hline & -1 & 0 & 1 \\
\hline-1 & $x$ & $x$ & $x$ \\
\hline 0 & 1 & 1 & 1 \\
\hline 1 & 1 & 1 & 1 \\
\cline { 2 - 4 } & &
\end{tabular}

Gdy opisaną wyżej metodę prowadzi się cyklicznie, aż do braku zmian w analizowanym obrazie, uzyskuje się przekształcenie zwane SKIZ (ang. Skeleton by Influence Zone ). Skrót ten oznacza szkielet strefy wpływów. Strefa wpływów danego punktu definiowana jest jako zbiór wszystkich punktów obrazu, dla których odległość do danego punktu jest mniejsza niż do pozostałych. Przekształcenie to posiada jednak szczególną wadę. Powstałe w jego wyniku figury mają bardzo nieregularny brzeg $\mathrm{z}$ licznymi wąskimi i głębokimi wklęsłościami [7].

VII - Filtr medianowy - wyrównanie krawedzi elementów obrazu. Filtracja obrazu opiera się na wykorzystaniu funkcji splotu cyfrowego. Najczęściej stosuje się filtry liniowe. Większość tego typu filtrów ma jedną wspólną cechę, tj. występuje efekt utraty informacji na temat drobnych szczegółów i krawędzi przetwarzanych obrazów. Lepsze efekty dają w tym zakresie filtry nieliniowe, wybierające dla przetwarzanego punktu na obrazie wynikowym jedną $\mathrm{z}$ wartości z jego otoczenia na obrazie źródłowym. Wybór ten dokonywany jest według pewnej reguły, która w ogólnym przypadku może być dowolna. Najczęściej spotykanym przykładem filtru działającego na tej zasadzie jest filtr wykorzystujący medianę. Filtr medianowy jest filtrem mocnym, gdyż ekstremalne wartości, znacznie odbiegające od średniej, nie mają wpływu na wartość, jaką filtr przekazuje na swoim wyjściu. Filtr medianowy bardzo skutecznie eliminuje wszelkie lokalne szumy, nie powodując ich rozmazywania na większym obszarze, co jest charakterystyczne dla wszystkich filtrów konwolucyjnych.

VIII - Morfologiczny filtr częściowy - usuwanie elementów o zbyt dużym obwodzie. Operacja morfologiczna polegająca na usunięciu z obrazu elementów, których obwód nie mieści się w wyznaczonym zakresie. Wielkość rejestrowanej plamki świetlnej zależy od źródła światła oraz od gabarytów przewodu jezdnego. Możliwe jest zatem odrzucenie elementów, których obwód jest znacząco większy od spodziewanego, albo też znacząco mniejszy.

IX - Filtr dolnoprzepustowy - usuwanie zaklóceń z obrazu. Najbardziej typowe zastosowanie filtracji polega na usuwaniu zakłóceń z obrazu. Przy tego typu zastosowaniu korzystne jest używanie $\mathrm{z}$ prostego filtru uśredniającego, którego macierz konwolucji ma postać:

\begin{tabular}{|c|c|c|c|}
\hline & -1 & 0 & 1 \\
\hline-1 & 1 & 1 & 1 \\
\hline 0 & 1 & 1 & 1 \\
\hline 1 & 1 & 1 & 1 \\
\cline { 2 - 4 }
\end{tabular}




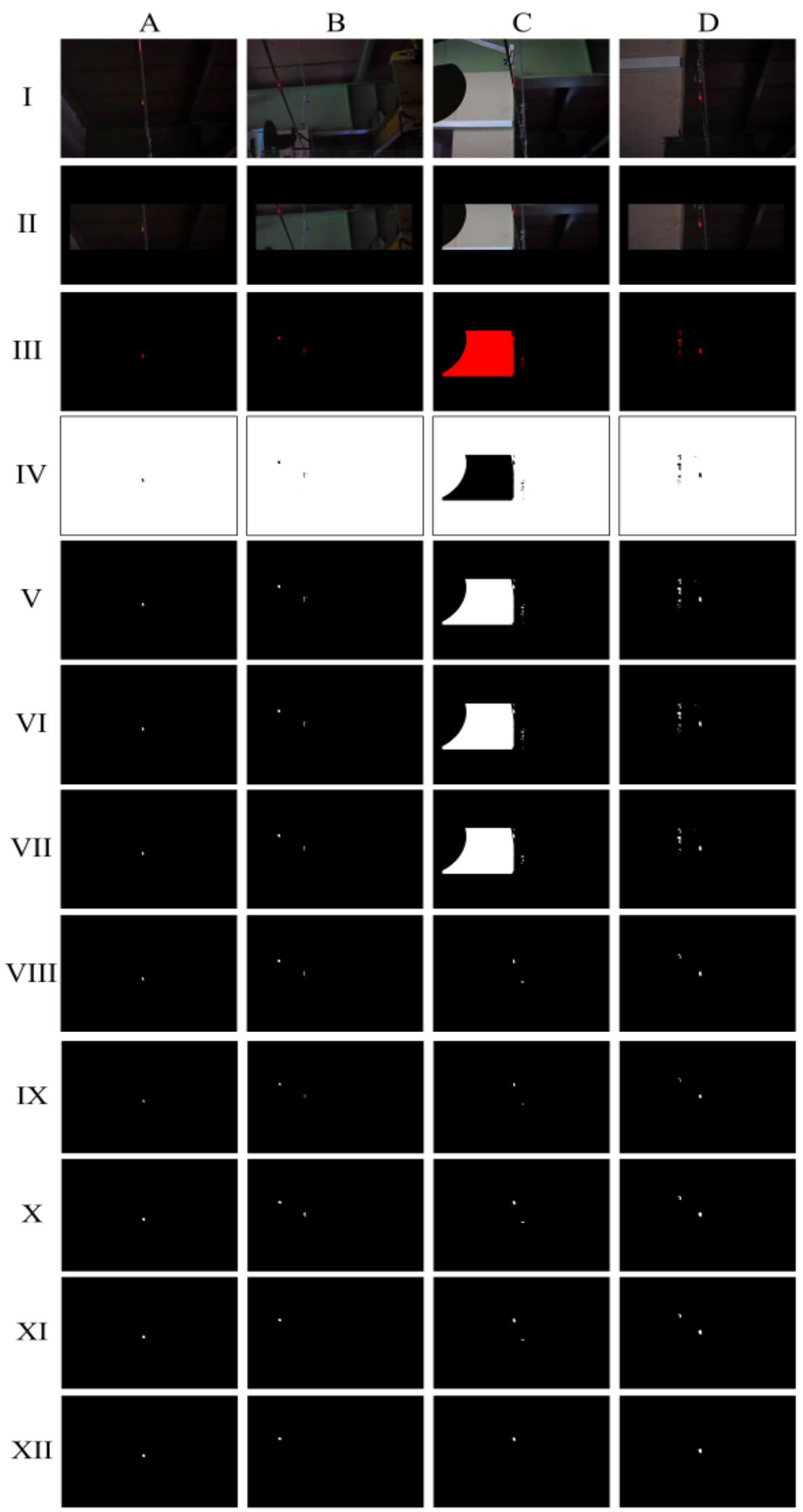

Rys. 7. Wyniki badań laboratoryjnych - przykłady prób pozytywnych 


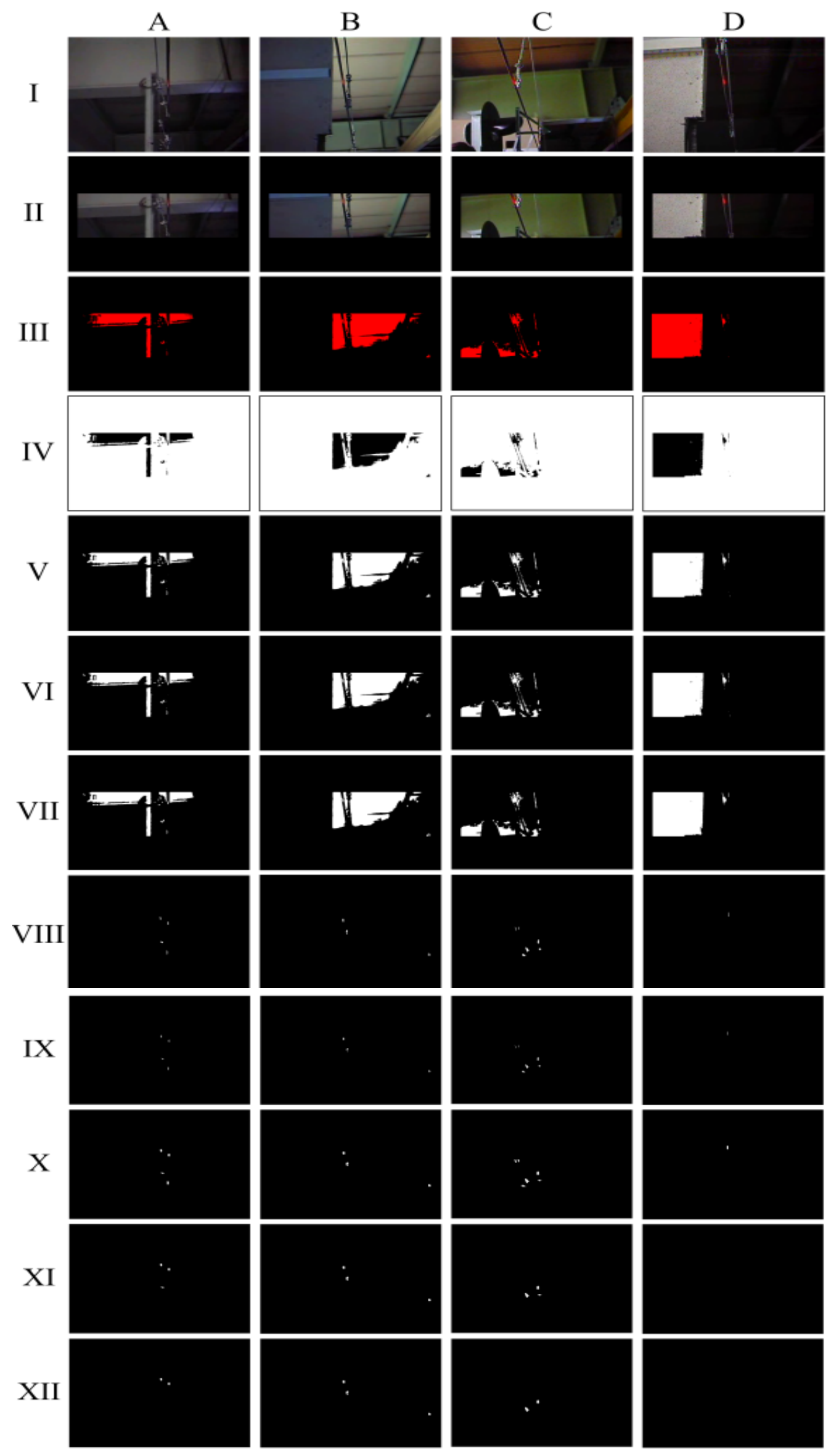

Rys. 8. Wyniki badań laboratoryjnych - przykłady prób częściowo pozytywnych (A i B) oraz negatywnych (C i D) 
Filtr uśredniający usuwa drobne zakłócenia $\mathrm{z}$ obrazu. Znacznemu osłabieniu, ale i pewnemu rozmazaniu ulegaja pojedyncze czarne punkty na jasnym tle lub jasne plamki na tle ciemnym. Wygładzane są również drobne zawirowania krawędzi obiektów.

$\mathbf{X}$ - Dylatacja - wygładzenie konturu elementów obrazu.

XI - Morfologiczny filtr częściowy - usuwanie elementów o zbyt dużej szerokości.

XII - Morfologiczny filtr częściowy - usuwanie elementów o zbyt dużej wysokości.

Po zrealizowaniu ostatniej operacji rezultatem jest obraz wynikowy. Powinien on zawierać białą plamkę na czarnym tle, czyli pożądany obraz do analizy właściwej.

\section{Wyniki badań laboratoryjnych}

Przeprowadzono badania przy wykorzystaniu fizycznego, laboratoryjnego modelu sieci trakcyjnej wykonanego w skali 1:5. Zarejestrowano obrazy różniące się w sposób znaczny, jeśli chodzi o poziom oświetlenia tła. Wybrane klatki poddano obróbce przy wykorzystaniu algorytmu przedstawionego powyżej. $\mathrm{Na} 30$ przeprowadzonych prób pozytywny wynik uzyskano w 13 przypadkach. Kolejnych 5 prób zakończyło się wynikiem częściowo pozytywnym. Pod pojęciem wyniku częściowo pozytywnego rozumie się taką sytuację, gdy obraz wynikowy zawiera, oprócz plamki właściwej, będącej obrazem przewodu jezdnego, inną plamkę lub plamki będące zakłóceniami, które nie zostały wyeliminowane przez algorytm obróbki. 12 prób zakończyło się wynikiem negatywnym, tzn. nie udało się uzyskać obrazu przewodu jezdnego. Wyniki dla przykładowych prób zakończonych pozytywnie pokazano na rys. 7 .

Można zauważyć, że szybkość dochodzenia do prawidłowego wyniku jest różna $\mathrm{w}$ zależności od parametrów obrazu wejściowego. W przykładzie A już trzecia operacja (przekształcenie LUT) pozwoliła na uzyskanie pożądanego obrazu. W pozostałych trzech przypadkach dopiero końcowe etapy algorytmu pozwoliły na otrzymanie właściwego wyniku. Jednak w sytuacji, gdy obraz przewodu jezdnego zostanie uzyskany na którymś z wcześniejszych etapów obróbki, kolejne kroki nie wpływają negatywnie na wynik. Jest to zgodne $\mathrm{z}$ postawionymi założeniami.

Wybrane wyniki dla prób, które zakończyły się częściowo pozytywnie oraz negatywnie przedstawiono na rys. 8.

W przypadku wyników częściowo pozytywnych, oprócz obrazu przewodu jezdnego widoczne są na obrazie plamki o wymiarach podobnych do tej odpowiadającej przewodowi, przez co algorytm obróbki ich nie usunął. Dla wyników negatywnych możliwe jest otrzymanie albo obrazu fałszywego, gdzie uzyskana plamka nie jest obrazem przewodu jezdnego (przykład C), albo całkowitego braku wyniku (obraz D).

\section{Podsumowanie}

Opracowany algorytm obróbki wstępnej obrazu do celów pomiaru położenia przewodu jezdnego sieci trakcyjnej pozwolił, dla przykładowych warunków pomiarowych, na uzyskanie prawidłowego rezultatu w 43\% przypadków. $17 \%$ stanowiły wyniki częściowo prawidłowe, a 40\% wyniki nieprawidłowe. Gdyby obróbce miały być poddane niezależne obrazy nieruchome, taki wynik należałoby uznać za niesatysfakcjonujący. Należy jednak pamiętać, że w proponowanej metodzie pomiarowej sygnałem jest sekwencja filmowa. Możliwe jest zatem, na podstawie prawidłowych i częściowo prawidłowych obrazów, uzyskać metodą interpolacji i eliminacji (czyli korekcji błędu) położenie przewodu jezdnego również dla klatek, dla których algorytm nie dał prawidłowego wyniku pomiarowego. Oczywiście należy dążyć do tego, by procent wyników prawidłowych był jak największy. Na podstawie badań stwierdzono, że w tym celu należy:

- $\quad$ zastosować źródło światła o możliwie dużej intensywności, tak by jaskrawość plamki świetlnej odbitej od przewodów jezdnych była jak największa;

- źródło światła powinno być monochromatyczne, tzn. charakteryzować się jedną długością fali;

na obiektyw kamery należy założyć filtr optyczny wstępnie eliminujący promieniowanie o długościach fali innych niż długość emitowana przez szczelinowe źródło światła.

Zastosowanie tych środków pozwoli na zdecydowane zmniejszenie poziomu promieniowania zakłócającego i tym samym obróbka obrazu będzie mniej kłopotliwa. Należy mieć jednak świadomość, że całkowita eliminacja promieniowania zewnętrznego będzie bardzo trudna, zwłaszcza gdy pomiary będą wykonywane w godzinach porannych i wieczornych, kiedy słońce znajduje się nisko nad horyzontem (w sytuacji, gdy światło zewnętrzne odbija się od dolnej powierzchni przewodu plamka jest niewidoczna). Nie jest więc wykluczone, że w sytuacjach ekstremalnych przeprowadzanie pomiarów przy wykorzystaniu tej metody nie będzie możliwe. Rozstrzygnięcie tego problemu wymaga jednak przeprowadzenia szeregu prób w warunkach terenowych.

\section{Literatura:}

[1] Giętkowski Z., Karwowski K., Mizan M.: Diagnostyka sieci trakcyjnej. Wydawnictwo Politechniki Gdańskiej, Gdańsk 2009

[2] Skibicki J.: Bezkontaktowa metoda lokalizacji przewodu jezdnego sieci trakcyjnej. SEMTRAK 2010, materiaty konferencyjne, Kraków - Zakopane, 2010

[3] Relf Ch. G.: Image Acquisition and Processing with Lab VIEW, CRC Press, Boca Raton 2004

[4] Fontoura Costa L., Marcondes Cesar Jr. R.: Shape Analysis and Classification, CRC Press LLC, 2001

[5] Farid H.: Fundamentals of Image Processing. http://www.cs.dartmouth.edu/ farid, dostęp z 30.07.2011

[6] Russ J. C.: The Image Processing Handbook (4th ed.), CRC Press, 2002

[7] Tadeusiewicz R., Korohoda P.: Komputerowa analiza i przetwarzanie obrazów. Wydawnictwo Fundacji Postępu Telekomunikacji, Kraków 1997 